\title{
OBSTETRIC RECORD OF THE CYPRUS EMERGENCY JULY 1974 TO JULY 1975
}

\author{
LIEUTENANT-COLONEL K. D. PRINTER, M.B., F.R.C.O.G., R.A.M.C.* \\ British Military Hospital, Dhekelia
}

SUMMARY: A review of the obstetric work load during the Cyprus emergency has shown that the Army Obstetric Service can cope with an unexpected acute obstetric load, working under difficult circumstances, and still be able to produce gratifying end results, reflected in a Perinatal Mortality of 10/1000 total births.

This is an account of the problems, their management and results, of a considerable number of obstetric emergency cases dealt with by the Obstetric Division of the British Military Hospital (B.M.H.), Dhekelia, during and after, the start of hostilities 'the Cyprus troubles' on 15 July 1974, up to a period of 12 months, till 31 July 1975.

The obstetric division has a total of 15 beds, staffed by 5 midwives, plus auxiliary staff. There is one consultant assisted by a part-time medical officer who holds the D.R.C.O.G. The average monthly delivery rate, prior to the emergency was about 13, all booked cases, nearly all of them being dependants of British servicemen or entitled United Kingdom (U.K.) based civilians.

On 15 July 1974, hostilities broke out between the Greeks and the Turks on the island, resulting in the evacuation of all British Service families and U.K. based civilians from the dormitory towns of Nicosia, Larnaca and Famagusta (Fig. 1) into the Eastern Sovereign Base Area (S.B.A.) of Dhekelia prior to their further evacua-

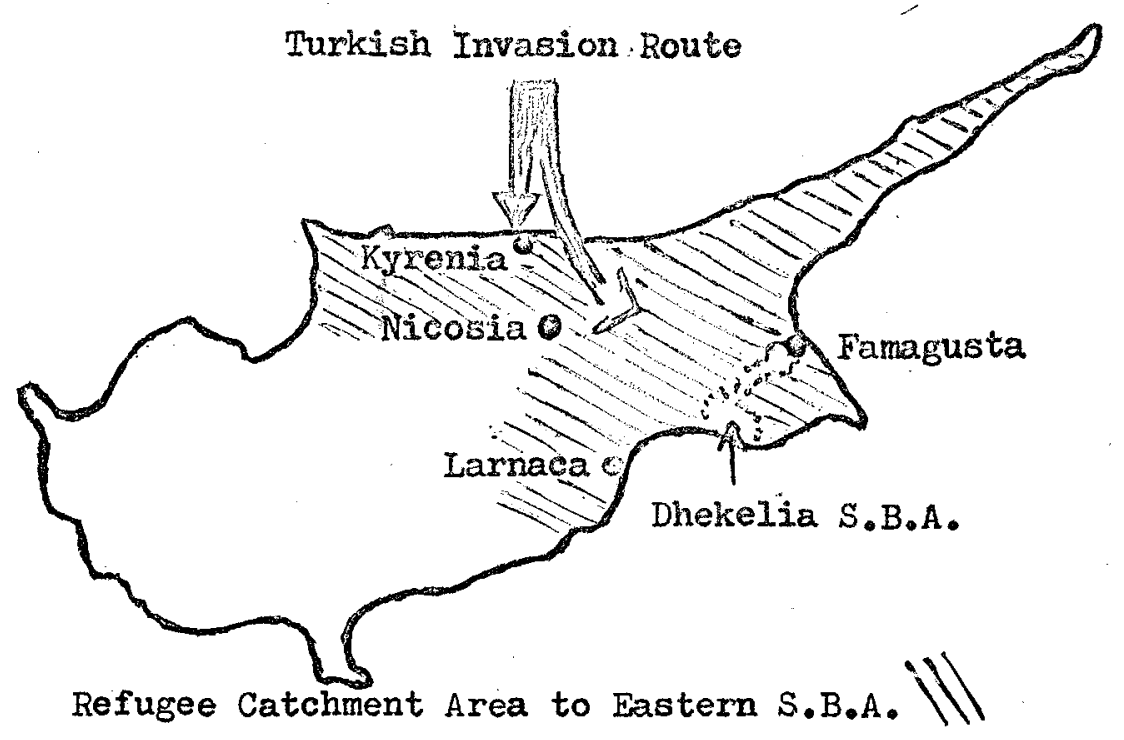

Fig. 1.

"Now: Military Hospital. Golchester, Essex. 
tion back to the U.K. Amongst these were quite a few pregnant women. At the same time, about 80,000 Cypriot refugees (mostly Greeks) from the surrounding towns and villages, converged on the Eastern S.B.A. of Dhekelia. The hospitals available at that time, were a local 60 bedded hospital at Larnaca, about 8 miles from Dhekelia, and the B.M.H. at Dhekelia.

Soon after the start of hostilities on 15 July 1974, nearly the entire local labour force employed in the B.M.H. area (ward maids, cleaners, kitchen and laundry staff, and others) went absent, causing further considerable extra work on the existing limited and over-stretched staff of the hospital. But for the work of the numerous volunteers from service families and the devotion to duty of the existing staff, the working of the B.M.H. could not have been maintained. An extra 15 bedded lyingin ward had to be opened up towards the end of July 1974 and manned by the existing staff, to take postpartum refugee patients, the majority of whom had no homes to go to and lived in temporary tents and makeshift homes. By this time there were nearly 80,000 displaced persons in and around the Eastern S.B.A. Pending the arrival of extra staff from the U.K., mobilisation of the existing dormant nursing resources from the Dhekelia Garrison was carried out in order to man the very heavy extra load by the B.M.H. The relief crew from the U.K. arrived by the end of September 1974. By December 1974 when the relief crew returned to the U.K., the total number of displaced persons around the Eastern S.B.A. had settled down to about 25,000 .

Table I shows the work load from July 1974 to July 1975, during which time

Table I

Monthly deliveries, Service and local Cypriot patients

\begin{tabular}{|c|c|c|c|c|}
\hline Month & $\begin{array}{l}\text { a. Service and } \\
\text { U.K. based } \\
\text { civilians }\end{array}$ & $\begin{array}{l}\text { b. Cypriot } \\
\text { (Local) }\end{array}$ & $\begin{array}{c}\text { Cypriot } \\
\text { (Unbooked) }\end{array}$ & $\begin{array}{l}\text { Total } \\
a \text { and } b\end{array}$ \\
\hline May 74 & 16 & 一 & 一 & 16 \\
\hline June 74 & 10 & 一 & - & 10 \\
\hline July 74 & 21 & 7 & 5 & 28 \\
\hline August 74 & 17 & 50 & 46 & 67 \\
\hline September 74 & 5 & 61 & 60 & 66 \\
\hline October 74 & 6 & 50 & 40 & 56 \\
\hline November 74 & 6 & 32 & 30 & 38 \\
\hline December 74 & 4 & 20 & 18 & 24 \\
\hline January 75 & 4 & 26 & 16 & 30 \\
\hline February 75 & 6 & 23 & 10 & 29 \\
\hline March 75 & 5 & 40 & 14 & 45 \\
\hline April 75 & 2 & 24 & 8 & 26 \\
\hline May 75 & 1 & 29 & 7 & 30 \\
\hline June 75 & 5 & 21 & 2 & 26 \\
\hline July 75 & 3 & 26 & 2 & 29 \\
\hline
\end{tabular}


Table II

Monthly workload July 1974 to July 1975

\begin{tabular}{|c|c|c|c|c|c|c|c|c|c|c|c|c|c|}
\hline \multirow[t]{2}{*}{$\begin{array}{l}\text { Month/Year } \\
\text { 1974-1975 }\end{array}$} & \multicolumn{2}{|c|}{$\begin{array}{l}\text { Normal } \\
\text { delivery }\end{array}$} & \multicolumn{2}{|c|}{ Forceps } & \multicolumn{2}{|c|}{ Venthouse } & \multicolumn{2}{|c|}{ Breech } & \multicolumn{2}{|c|}{ L.S.C.S. } & \multicolumn{2}{|c|}{ Foetal los? } & \multirow[t]{2}{*}{ Remarks } \\
\hline & $\mathbf{B}$ & NB & $\mathrm{B}$ & $\mathrm{NB}$ & B & NB & B & NB & B & $\mathrm{NB}$ & B & סNB & \\
\hline July 74 & 17 & 5 & 2 & - & 1 & - & - & - & 2 & - & $1 \mathrm{SB}(\mathrm{ND})$ & 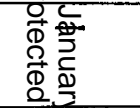 & $\begin{array}{l}\text { SB-British-Hydroce- } \\
\text { phalous-41/52-ND } \\
-7.0 \mathrm{lb}\end{array}$ \\
\hline August 74 & 15 & 44 & 1 & - & - & 2 & 1 & $\longrightarrow$ & 4 & - & - & 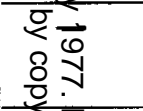 & $\begin{array}{l}\text { Exchange transfusion } \\
\times 3-\mathrm{NB}-\text { Anti } A \\
\text { incompatability }\end{array}$ \\
\hline September 74 & 3 & 50 & 2 & 4 & - & 2 & 1 & 4 & 1 & 3 & $\rightarrow$ & 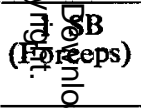 & $\begin{array}{l}\text { SB-Compound pre- } \\
\text { sentation-Forceps. } \\
\text { BW-3 lb } 8 \text { oz }\end{array}$ \\
\hline October 74 & 12 & 33 & 2 & 2 & - & 1 & $\rightarrow$ & 2 & 2 & 2 & $\rightarrow$ & $\frac{\tilde{a}}{\frac{\alpha}{\alpha}}$ & \\
\hline November 74 & 6 & 19 & - & 6 & $\rightarrow$ & 2 & 2 & 2 & $\rightarrow$ & 1 & - & 1 害 & $\begin{array}{l}\text { SB-Mixed APH-ND } \\
-\mathrm{BW} 5 \mathrm{lb} 6 \mathrm{oz}\end{array}$ \\
\hline December 74 & 6 & 12 & - & 3 & $\longrightarrow$ & 2 & $\rightarrow$ & - & - & 1 & - & $\frac{2}{2}$ & \\
\hline January 75 & 10 & 14 & 1 & 2 & - & $\rightarrow$ & - & $\rightarrow$ & $\rightarrow$ & - & $\rightarrow$ & 产 & \\
\hline February 75 & 7 & 15 & 1 & 1 & 1 & 1 & $1 \mathrm{SB}$ & - & 2 & 1 & $1 \mathrm{SB}$ & 亨 & $\begin{array}{l}\text { SB-Breech at term- } \\
\text { IUD-7 lb } 4 \mathrm{oz} \text {. } \\
\text { Booked refugee }\end{array}$ \\
\hline March 75 & 24 & 12 & 1 & 2 & 2 & $\longrightarrow$ & 2 & $\rightarrow$ & 3 & - & - & స్ & \\
\hline April 75 & 14 & 7 & 2 & - & 1 & 1 & 1 & - & - & - & 二 & 产 & \\
\hline May 75 & 20 & 7 & 2 & - & - & - & 1 & $\longrightarrow$ & 一 & - & - & 을 & \\
\hline June 75 & 18 & 2 & 3 & $\rightarrow$ & 1 & - & 1 & - & 1 & - & - & 용 & \\
\hline July 75 & 22 & 2 & 1 & $\rightarrow$ & - & $\rightarrow$ & 1 & $\rightarrow$ & 3 & $\omega$ & - & $\begin{array}{c}1 \text { NND } \\
\text { 을 } \\
. \quad 7 \\
\end{array}$ & $\begin{array}{l}\text { NND-NB-Premature } \\
\text {-Pulmonary haemorr- } \\
\text { hage. BW } 3 \mathrm{lb} 12 \mathrm{oz}\end{array}$ \\
\hline $\begin{array}{l}\text { Totals } \\
\text { (496) }\end{array}$ & 174 & 222 & 18 & 20 & 6 & 11 & 11 & 8 & 18 & 8 & 2 & $\frac{3}{3}$ & (1) \\
\hline otes $-B=B o$ & & $V B=U n$ & te & NI & orn & deliv & . & i & & $D=1$ & natal dea. & 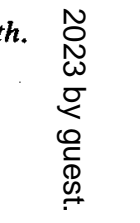 & \\
\hline
\end{tabular}


494 babies were delivered ( 85 British and 409 local Cypriot). There were 258 emergency unbooked cases (52 per cent). During the first half of the emergency period (July to December 1974), out of a total of 279 cases, 199 were unbooked (71 per cent). During the second half (January to July 1975), out of a total of 215 cases, 59 were unbooked ( 27.4 per cent). The reason for this drop in unbooked cases was the result of efforts made to induce the local Cypriot refugee patients to attend our antenatal clinic, instead of just arriving at the hospital when labour commenced.

Table II shows' the total monthly work load over the period under review. August, September and October 1974 were the most busy months (the extra staff from the U.K. arrived at the end of September 1974), during which time the large majority of admitted cases were unbooked and in labour. It is gratifying to note that in spite of all the difficulties faced at the time, only one baby (S.B.) was lost during that period, and that was the result of a compound presentation in a spontaneous premature labour.

Table III shows that 42 per cent out of a total of 19 breach presentations were unbooked. One baby was lost, a sudden intra-uterine death near term, in a local Cypriot booked case. No foetal loss was recorded in the unbooked cases. A foetal mortality of 5.2 per cent and a Lower Segment Caesarean Section (L.S.C.S.) rate of 26 per cent is considered reasonable in view of the number of unbooked cases.

Forceps Rate of 7.6 per cent was noted (Table IV). Seventy-three per cent of the total number of forceps cases were again in unbooked patients. The commonest cause was delay in the second stage of labour ( 73 per cent), no appreciable difference was noted between booked and unbooked cases there.

The L.S.C.S. rate was 5.2 per cent (Table V), a third of these were unbooked cases. Out of the 9 unbooked emergency cases that necessitated a L.S.C.S., there were 3 cases of failed trial labour due to cephalopelvic disproportion (C.P.D.); three breech presentations-one with previous L.S.C.S., one with previous bad obstetric history, and one senior primip; two cases of unstable lie-one a brow presentation, and the other a persistent oblique lie in labour. In one case there was failure to progress in the first stage due to incordinate uterine action. There was no foetal loss.

No significant increase in the live low birth weight baby rate was observed (Table VI), in spite of the fact that 52 per cent of cases were unbooked. Only one baby $(3 \mathrm{lb} 8 \mathrm{oz}$ ) was lost out of a total of 20 live low birth weight babies. The total Perinatal Mortality (Table VII) of 10 per 1000 total births is quite acceptable, considering that 52 per cent of cases were unbooked, and the available resources rather limited. One baby was lost out of 85 booked British cases, and 4 babies were lost out of 409 local Cypriot cases, only one of these was booked.

Table III

Breech deliveries-Total of 19 cases Mortality of breech presentation of $\mathbf{5 . 2}$ per cent

\begin{tabular}{|l|c|c|l|}
\hline \multicolumn{1}{|c|}{ Category } & Assisted breech delivery & L.S.C.S. & \multicolumn{1}{c|}{ Remarks } \\
\cline { 1 - 3 } Booked & 9 & 2 & 1 Intra-uterine death \\
\hline Unbooked & 5 & 3 & No foetal loss \\
\hline
\end{tabular}


Table IV

Forceps deliveries-Total of 38 cases Forceps rate of 7.6 per cent

\begin{tabular}{|l|c|c|}
\hline \multicolumn{1}{|c|}{ Indications } & Unbooked & Booked \\
\hline Delay second stage & 15 & 13 \\
\hline Persistent occipito-posterior-deep transverse arrest & 2 & 3 \\
\hline Foetal distress & 3 & 2 \\
\hline
\end{tabular}

Table V

Lower segment of caesarean sections Total of 26 cases. Rate of 5.2 per cent

\begin{tabular}{|l|l|c|}
\hline \multicolumn{1}{|c|}{ Indications } & British & Local Cypriot \\
\hline Failure to progress in first stage & $3(\mathrm{~B})$ & 1 (NB) \\
\hline Cephalopelvic disproportion & $2(\mathrm{~B})$ & $5(3 \mathrm{NB} .2 \mathrm{~B})$ \\
\hline Previous lower segment caesarean section & - & 6 (B) \\
\hline Breech & 1 (B) & 4 (3 NB. 1B) \\
\hline Foetal distress and, or, dysmaturity & 2 (B) & - \\
\hline Unstable lie & - & 2 (NB) \\
\hline
\end{tabular}

Notes $-\mathrm{B}=$ Booked. $\mathrm{NB}=$ Unbooked.

Table VI

Live-born infants of low birth weight

Total of 20. Rate 3.8 per cent

\begin{tabular}{|c|c|c|c|}
\hline Weight & Died & Survived & Percentage mortality \\
\hline Less than $2 \frac{1}{2} \mathrm{lb}$ & - & - & - \\
\hline $2 \frac{1}{2}$ to $3 \frac{1}{2} \mathrm{lb}$ & - & $1 \mathrm{NB})$ & - \\
\hline $3 \frac{1}{2}$ to $4 \frac{1}{2} \mathrm{lb}$ & $1(\mathrm{NB})$ & $2(\mathrm{~B}) .3(\mathrm{NB})$ & 16.6 \\
\hline $4 \frac{1}{2}$ to $5 \frac{1}{2} \mathrm{lb}$ & - & $6(\mathrm{~B}) .7 \mathrm{NB})$ & - \\
\hline
\end{tabular}

Table VII

Foetal loss. Total number of babies born 494 British-85. Cypriot (local)-409

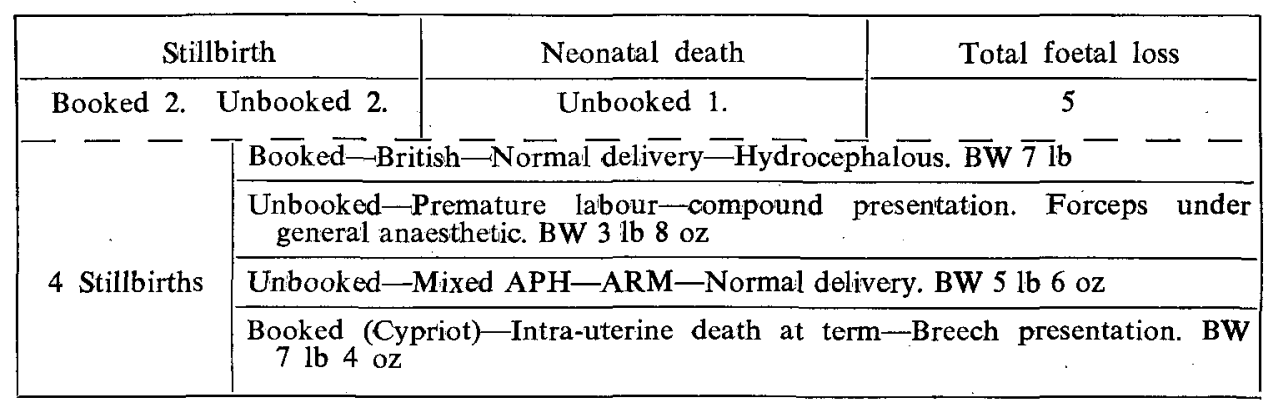

Notes. Perinatal mortality $10 / 1000$ total births. Perinatal mortality for unbooked cases $6 / 1000$ total births. Perinatal mortality for booked cases 4/1000 total births. 


\section{Acknowledgements}

My thanks to Colonel T. W. Brown, Late R.A.M.C., for the use of his case records of patients under his care until March 1975, and to the various members of the administrative and nursing staff, for the verbal accounts of the emergency, and to Mrs. J. Webb for typing this manuscript.

\section{Order of St. John of Jerusalem}

Notification has been received from the Secretary-General of the Grand Priory in the British Realm of the Most Venerable Order of the Hospital of St. John of Jerusalem that the following officers have been advanced in the order or appointed Serving Officers of the Order.

\section{Advanced tó Commander}

Lieutenant-General R. P. Bradshaw, Q.H.P., M.R.C.S., L.R.C.P., F.R.C.Path., M.F.C.M., D.T.M.\&H.

\section{Appointed Officer Brother}

The Director-General of Army Medical Services has written a personal letter congratulating them on their appointment.

Brigadier N. G. Kirby, O.B.E., M.B., Ch.B., F.R.C.S. Lieutenant-Colonel J. T. Coull, M.B., Ch.B., F.R.C.S. Major W. R. Short, M.B., Ch.B. Lieutenant-Colonel N. E. C. Bamford, T.D., M.B., Ch.B., R.A.M.C. (T.A.V.R.). Lieutenant-Colonel M. L. Fisher, T.D., M.B., B.S., M.R.C.G.P., D.Obst.R.C.O.G., R.A.M.C. (T.A.V.R.). Lieutenant-Colonel B. L. Ardill, T.D., M.D., F.R.C.S., R.A.M.C. (T.A.V.R.). Major I. M. Calder, T.D., M.B., Ch.B., D.M.J., F.R.M.S., R.A.M.C. (T.A.V.R.). 